\title{
Mind the (Justiciability) Gap: Non-judicial Remedies and International Legal Accountability for Environmental Damages
}

\section{Vanessa Richard}

The "global governance" paradigm has considerably modified the way responsibilities, in the broad sense of the word, are considered at the international level. Global governance is indeed a multi-faceted notion that intends to go beyond the traditional governmental decision-making patterns in order to reflect the complexification of the decision-making fora, actors and processes that address certain globalized issues. It refers to "the sum of many ways, individuals and institutions, public and private, manage their common affairs. It is a continuing process through which conflicting or diverse interests may be accommodated and co-operative action taken. It includes formal institutions and regimes empowered to enforce compliance, as well as informal arrangements that people and institutions either have agreed to or perceive to be in their interest." In many respects, the global governance approach reveals phenomena that hardly fit in the international law framework and can hardly be phrased in terms of international law proper.

The development of modern international law is largely based on the horizontal "Westphalian legal order," characterized by absolute territorial sovereignty and the legal equality of States. It entails that there can be no supra-national authority (verticality being circumscribed to domestic legal

1 Commission on Global Governance, Our Global Neighborhood: The Report of the Commission on Global Governance 4 (1995). 
orders) and that no obligation can be imposed on a State without its consent (consensualism). The techniques of the legal framing of inter-state relations have, of course, experienced considerable evolutions, from contractbased relations between sovereigns to multilateralism and the creation of intergovernmental organizations. Some of these evolutions clearly reveal certain changes in the values international law is expected to protect: for instance, the emergence of a "community of interests" has led to depart from strictly reciprocal obligations ${ }^{2}$ and fostered the development of nonreciprocal obligations under which a party must keep complying with its obligations even when others do not. This is typically the case in international environmental or human rights law. The techniques used by international law have changed, and so have the activities and kinds of persons covered by international law. Since the end of World War II, it has considerably developed both in substantive and institutional terms, in order to answer increasing calls for worldwide and regional legal frameworks in very diverse matters. Such legal developments gave birth to many sub-systems - such as peacekeeping and international security law, international trade law, human rights, international environmental law-each one of them operating in its own context and institutions, following its own logic. The proliferation of specialized international organizations created by conventional legal regimes poses many effectiveness ${ }^{3}$ problems because these regimes do not always

2 Reciprocal obligations entail that the duty to comply with one's commitments is conditioned by the fact the other parties do the same.

3 Depending on the author, "effectiveness" describes whether "a rule. . . leads to observable, desired behavioral change" (Kal Raustiala, Compliance \& Effectiveness in International Regulatory Cooperation, 32 Case W. Res. L. Rev. 387, 387 (2000).), or "whether the purposes of the agreement are being achieved, and more generally, whether the agreement as designed is effective in addressing the problem for which it was negotiated" (Edith Brown Weiss, Understanding Compliance with International Environmental Agreements: The Baker's Dozen Myth, 32 U. Rich. L. Rev. 1555, 1555 (1999).). In the present paper, effectiveness refers to the broader definition of the term, that is to say whether an instrument or mechanism is effective in addressing the problem for which it was created and/or leads to the desired behavioural change. 
"fit" the issues they are expected to tackle, because of their "interplay," or else because of the spatial and temporal "scales" involved. ${ }^{4}$ The development of international institutions also raises questions as to their responsibility. Beside this substantive and institutional remarkable spread, international law witnessed deep transformations regarding its sources and actors. Henceforth, one cannot ignore that in addition to substantive international law, which requires the States' consent, soft law-stemming from declarations, resolutions, guidelines, agendas or the like - plays an important role in the development, the interpretation, and the perception of what is applicable law. One can also note that some legal consequences may result from non-binding instruments. ${ }^{5}$ With the multiplication of "governance sites" ${ }^{\circ}$ and actors, decision and law-making seems to move away from a center.

However, international law remains primarily intended as the legal framework of inter-state relations, made by and for States. It is an "atypical system" that "endeavours to serve as any legal order in spite of the absence of an institutional structure of its own, which could have guaranteed it a minimum autonomy regarding its subjects. Such original aspect determines the terms of its relative hold on their behavior." "A global governance approach requires exploring areas that lay beyond this formal mould, and consider the role that non-binding law ("soft law") and non-subjects of

4 The Institutional Dimensions of Environmental Change: Fit, Interplay, and SCAle (Oran Young ed., 2000).

5 Commitment and Compliance: The Role of Non-Binding Norms in the International Legal System (Dinah Shelton ed., 2000).

6 Francis Snyder, Governing Economic Globalisation: Global Legal Pluralism and European Law, 5 Eur. L. J. 334 (1999).

7 'système juridique atypique' qui 's'efforce de remplir les fonctions de tout ordre juridique malgré l'absence d'une armature institutionnelle propre, qui aurait pu lui garantir un minimum d'autonomie à l'égard de ses sujets. Cette originalité détermine les conditions de son emprise relative sur leur comportement': Pierre-Marie Dupuy, Libre parcours à travers la richesse d'une cuvre: notes de lecture sur les travaux de G. Abi-Saab, in The International Legal System in Quest of Equity and Universality: Liber Amicorum Georges Abi-Saab 10 (L. Boisson de Chazournes and V. Gowland-Debbas eds., 2001). 
international law (epistemic communities, civil society, private sector, et cetera, i.e. neither States nor international organizations) actually play in decision-making and law-making. Such an approach also requires exploring the way some activities or claims for increased global regulation pierce the veil of States.

Likewise, international environmental issues seem to challenge certain traditional concepts of international law, in particular because real improvement in the legal framework of cooperation in order to protect the environment would require a quantum leap in the understanding of what "community of interests" and what "global public goods" entail. More prosaically and for the purpose of this paper, suffice is to recall the difficulties encountered when manipulating international State responsibility when disputes arise from environmental harm. ${ }^{8}$ Obligations rest on the prevention principle and traditional compensation means are not necessarily appropriate (for example, impossible restitutio in integrum, unsatisfactory monetary compensation). Because environmental obligations are not grounded in reciprocity but in the protection of a common interest, which legal interest is disputed. As in human rights matters, accepted reactions to noncompliance - such as the possibility of triggering international responsibility, the adoption of countermeasures, or the suspension of the participation of the non-compliant party - can actually turn out to be counter-productive with regard to the purpose of environmental agreements and can be a deterrent to a large participation of States. ${ }^{9}$ In addition, discrepancies between agreed environmental commitments and the reality of their implementation are at least as much due to a lack of capacities (unavailable or insufficient know-

8 See in this book the contribution of Sandrine Maljean-Dubois.

9 Pierre-Marie Dupuy, À propos des mésaventures de la responsabilité internationale des États dans ses rapports avec la protection de l'environnement, in Les hoMMES ET L'ENVIRONNEMENT, EN Hommage À A. Kiss 269 (Michel Prieur ed., 1998). 
how, and/or material, and/or technical resources) as to a lack of willingness to comply.

This picture gains additional dimensions when non-compliance, reaction to non-compliance and justiciability are considered from the angle of victims, that is to say, the people affected by environmental damages. In that respect, three basic observations are combined. Firstly, private individuals or, more broadly, civil society, have little access to international remedies. This issue is the subject of rich theoretical and practical debates this paper does not address, in particular, debates between the advocates of a stronger international binding dispute settlement system with greater access granted to private individuals ${ }^{10}$ and those of a large decentralization towards domestic fora of the settlement of disputes born from international obligations. ${ }^{11}$ Secondly, in the current institutional and political decisionmaking and law-making settings, international law cannot encompass all kind of activities that have environmental impacts. And this, not only from a material scope point of view, but also because living up to stronger regulations or social justice expectations would require the creation of a (or several) global regulatory regime(s) related to the activities of entities which are not subjects of international law, and more generally it would require comprehending activities which cannot be easily-or should not be artificially - linked to the jurisdiction of a State. Thirdly, the existence of international remedies directly available to affected people by and large depends on the type of actor who caused the damage, and on the law applicable to this actor. Given these observations, this paper endeavours to explore how international accountability can be triggered by affected people

10 Inter alia Antônio Augusto Cançado Trindade, The Access of Individuals to International Justice (2011); Rafael Domingo, The New Global Law (2010).

11 Harold Hongju Koh, Transnational Legal Process, 75 Neb. L. Rev. 181 (1996); Kenneth Abbott \& Duncan Snidal, Strengthening International Regulation through Transnational New Governance: Overcoming the Orchestration Deficit, 42 VAnd. J. Transnat'l L. 501 (2009). 
when no international liability mechanism is available. For that purpose, this paper addresses first the notion of accountability compared to that of legal responsibility strictly speaking, and builds on the notion of international legal accountability from the viewpoint of its external dimension (Part 1). This paper then distinguishes between three kinds of situation where international accountability mechanisms can be used by affected people, depending of the type of actor (State, international organization, private enterprise) who caused environmental harm, and then sketches out the role these mechanisms are intended to perform (Part 2). Finally, this paper emphasizes the main differences between international legal accountability and international liability mechanisms and the consequences they suggest from the viewpoint of people affected by environmental harm (Part 3).

\section{About International Legal Accountability}

"Accountability" is a catchword widely used in recent global governance literature as "a general term for any mechanism that makes powerful institutions responsive to their particular publics." $" 12$ The notion is vague but can be seen more precisely as "a relationship between an actor and a forum, in which the actor has an obligation to explain and to justify his or her conduct; the forum can pose questions and pass judgment, and the actor may face consequences." ${ }^{\prime 13}$ Triggering accountability then requires combining at least three elements:

(1) A set of standards in the eyes of which an entity has to justify

12 Richard Mulgan, Holding Power to Account: Accountability in Modern Democracies (2003), cited in Mark Bovens, Analysing and Assessing Accountability: A Conceptual Framework, 13 Eur. L. J. 447, 449 (2007).

13 Bovens, id, at 450; Andreas Schedler, Conceptualizing Accountability, in The SelfRestraining State: Power and Accountability in New Democracies 13, 17 (Andreas Schedler, Larry Diamond \& Marc Plattner eds., 1999). 
its behavior, and

(2) A mechanism able to bring accountable entities and accountholders together, and

(3) The mechanism is able to assess the observance of relevant standards and is able to draw consequences from nonobservance. $^{14}$

Delineated this way, "accountability" still applies to very different situations, and remains open to the application of varied standards by varied formal or informal mechanisms, related to varied relationships between the accountable entity and account-holders. By way of illustration, some authors distinguish between seven registers of accountability (electoral, hierarchical, supervisory, fiscal, legal, market, peer, and reputational $)^{15}$ while others distinguish between five accountability registers (electoral, hierarchical, supervisory, fiscal, and legal) based on two types of relationships (delegation or authority transfer for the first four registers, legal relationship as regards the fifth accountability register). ${ }^{16}$ Of course, one situation can mobilize several categories of accountability mechanisms at once.

Studies proposing a typology of accountability mechanisms seem to agree on the fact that the type of accountability first depends on the nature of the relationship between accountable entities and account-holders. Accountability has thus a legal nature when both are connected by a legal relationship. Seen from the angle of law, legal accountability obviously refers to stricto sensu legal responsibility: relevant standards are substantive legal

14 Ruth Grant \& Robert Keohane, Accountability and Abuses of Power in World Politics, 99 АM. Pol. Sci. Rev. 29, 29-30 (2005).

15 Id, at 35-37.

16 See for example Richard Stewart, Accountability, Participation, and the Problem of Disregard in Global Regulatory Governance, Draft Paper for the IILJ International Legal Theory Colloquium 15-17 (2008), http://iilj.org/courses/documents/2008Colloquium.Session4. Stewart.pdf (last visited 15 May 2013). 
norms, the relationship between accountable entities and account holders are legal (on the basis of rights and obligations) and delineated by applicable law, and the consequences are liability and the compensation means the law provides for. Although the area of international legal responsibility is bestmapped and constitutes the most legitimate ground for an analysis rooted in international law, circumscribing legal accountability to this particular conception seems simplistic when brought back to the main features of global governance and the stunning diversity of legal accountability issues they raised. The notion of legal accountability, when restricted to "familiar" situations of legal responsibility, has nothing new to offer and one can look down on its use as a not-so-subtle way of masking some recycling under a veneer of hype. However, it offers a very stimulating ground for discussion if applied to the many situations encountered on the contemporary international scene where standards have normative dimensions although their legal nature and value is soft, uncertain or disputed. Accountability can be considered as legal accountability not only when there is a clear and positive legal relationship between accountable entities and account-holders (because a contract binds both parties, or a treaty provides for the obligations or the firsts vis-à-vis others etc.), but also generally when the behavior of an entity can be assessed in the eyes of standards that have legal dimensions.

Seen in this light, international legal accountability goes beyond the notion of international legal responsibility and encompasses situations when an international actor has to justify itself in the eyes of internationally-defined standards.

International legal accountability, then, involves the legal justification of an international actor's performance vis-à-vis others, the assessment or judgment of that performance against international legal standards, and the possible imposition of consequences if the actor fails to live up to applicable legal 
standards. ${ }^{17}$

An open legal accountability approach allows taking into account situations where relevant standards belong to soft law (internal acts of international organizations, voluntary codes of conduct or guidelines, or the like) or else where the accountability mechanism is non-judicial and does not result in deciding on legal responsibility but has a non-compliance statement function and/or a problem-solving function.

Another clarification must be made when dealing with accountability, whether legal or not. Part of the haziness of the notion comes from the fact that it is very often used without distinguishing between the internal and external dimensions of "concrete practices of account giving." 18 As M. Bovens rightfully notes, the word is often used "interchangeably with 'good governance' or virtuous behavior."19 From an internal point of view, accountability refers to rules and processes that aim to ensure that an international actor acts virtuously (virtuously with regard to a set of prevailing paradigms and agreed commitments). Applied to States or international organizations, internal accountability has to do with elements that guarantee legitimacy and validity: the rule of law, democracy, transparency, balanced decision-making and reasoned decisions, due process, wise financial management, and so on. ${ }^{20}$ From an external point of view,

17 Jutta Brunée, International Legal Accountability through the Lens of the Law of State Responsibility, in 36 NeTH. Y. B. INT'L L. L. 3, 24 (2005) (emphasis in the original text).

18 Bovens, supra note 12, at 450 .

19 Id.

20 In addition to the works on accountability cited above, the way the International Law Association (ILA) has broken down and addressed the different dimensions of the legal accountability of international organizations gives a clear example of the variety of aspects that must be taken into account, and gives food for thought beyond the sole case of international organizations: See ILA, Accountability of International Organisations, Final Report, Berlin Conference 6-17 (2004), http://tinyurl.com/ba3h78r (last visited 13 May 2013); Ige F. Dekker, Making Sense of Accountability in International Institutional Law. An analysis of the Final Report of the ILA Committee on Accountability of International 
accountability refers to the fact that, beyond being accountable to accountholders who belong to its internal order (checks and balances between the different bodies of a State or an international organization, accounts given to citizens and employees, to shareholders and workers as regards private businesses), transnational/international entities account to all those affected by the negative impacts of its activities.

When those two dimensions are combined, the entity takes on its full responsibilities. The distinction between these two aspects of accountability is not only useful in comprehending its inner implications at the theoretical level, but it is also necessary for analysing what global environmental governance is still lacking with respect to legal accountability, how and why. Although good internal governance is very likely to have impacts on the capacity of an entity to assume its external responsibilities, the issues this paper deals with are essentially related to the external dimension of international legal accountability, that is to say this paper focuses on international non-judicial mechanisms that allow affected people to directly ask a transnational actor to account for its behavior with regard to international instruments, whether mandatory or not, and legal responsibility is left aside.

\section{International Accountability Mechanisms Available to Victims of Environmental Damages}

As regards their main features, international legal mechanisms of external accountability are by definition non-judicial (they are not tribunals, who decide on legal responsibility stricto sensu). At a closer look, it is obvious that they are much too specific to be analyzed according to basic distinctions such as:

Organizations from a Conceptual Legal Perspective, in 36 Neth. Y. B. INT'L L. 83 (2005). 
- The standards they apply belong either to hard or soft law: some assess behaviors in the eyes of hard, legally binding law but also and at the same time in the eyes of rules with a more uncertain legal value; some assess behaviors in the eyes of non-legally binding international instruments, but may nevertheless end up using legally binding international instruments to perform assessments.

- If these accountability mechanisms are non-judicial, then they are "soft enforcement" (supervision and control) devices: some obviously are, but it is only partly the role of others.

All in all, the core feature is that international accountability mechanisms are totally tailored to the features of the frameworks they were created in. If only for the sake of clarity, it seems more appropriate to introduce them according to these categories of framework: accountability mechanisms created in the framework of States' international obligations, accountability mechanisms created in frameworks related to the impacts of international organizations' activities, and accountability mechanisms created in frameworks dealing with the impacts of businesses' transnational activities.

\subsection{International Legal Accountability Mechanisms for Environmental Damages Due to States}

As regards States' environmental obligations toward private individuals, domestic tribunals are considered to be able to decide and effective domestic remedies are considered to be available. When international obligations cannot be directly applied in domestic law, States are supposed to have adequately transposed their international obligations in domestic legislations. Usually, international law interferes as little as possible in the relations 
between States and private individuals. Besides, the responsibility States have of respecting the rights of individuals has limits. By and large, in order to be entitled to invoke a violation of one's internationally guaranteed rights by a State, one must be a citizen of that State or the violation must have occurred under the jurisdiction of that State.

In certain instances, however, multilateral environmental agreements (MEAs) allow individuals or groupings of individuals to directly invoke a violation of a State's obligations before an international accountability mechanism-usually referred to as a "non-compliance procedure"regardless of the existence of a right or direct legal interest. The underlying idea is that the protection of the environment benefits all and a violation of environmental obligations harms all. A crucial reason explaining States' acceptance of such direct access to international remedies is that this access has not been negotiated in the multilateral agreement itself, but has been provided for by the decisions of the MEA's Conference of the Parties (COP), relating to the mandate and procedure of the non-compliance mechanism of the agreement. At first a "little noticed phenomenon," 21 the role of the law adopted by treaty bodies in international law-making reflects collective learning by doing and is now put under full light and considered to be a major feature of international environmental law, ${ }^{22}$ especially from the viewpoint of compliance monitoring and control. ${ }^{23}$

21 Robin Churchill \& Geir Ulfstein, Autonomous Institutional Arrangements in Multilateral Environmental Agreements: A Little-noticed Phenomenon in International Law, 4 AM. J. INTL̇ L. $623(2000)$.

22 Jutta Brunée, COPing with Consent: Law-Making Under Multilateral Environmental Agreements, 1 Leiden J. INT'L L. 1, 15 (2002); Sandrine Maljean-Dubois \& Vanessa Richard, Mechanisms for the Monitoring and Implementation of International Environmental Protection Agreements, in IDDRI Working Paper Series 09/2004, http://www.iddri.org/Publications/ Collections/Idees-pour-le-debat/id_0409_maljeandubois.pdf(last visited 15 May 2013).

23 Implementation of International Environmental Law / La mise en ceuvre du droit De L'environnement (Sandrine Maljean-Dubois \& Lavanya Rajamani eds., 2011). Sandrine Maljean-Dubois, Les organes de contrôle du respect des dispositions internationales, in ACTEURS ET OUTILS DU DROIT DE L'ENVIRONNEMENT: DÉVELOPPEMENTS RÉCENTS, DÉVELOPPEMENTS (PEUT-Être) À Venir 249 (Benoit Jadot ed., 2010). 
Still, affected people do not have wide access to treaty-based noncompliance procedures. The possibility is hitherto limited to environmental agreements negotiated in the framework of the United Nations Economic Commission for Europe (UNECE) ${ }^{24}$ UNECE, set up in 1947 by the UN Economic and Social Commission (ECOSOC), brings together 56 countries located in the European Union, non-EU Western and Eastern Europe, SouthEast Europe and Commonwealth of Independent States and North America. It is intended to serve as a platform for facilitating greater economic integration and cooperation. ${ }^{25}$ Over the years, UNECE has also emerged as a spearhead for the elaboration of international environmental legal regimes. Three multilateral agreements the UNECE has given birth to admit that individuals or groupings of individuals can directly trigger a non-compliance procedure. More precisely, their COP decisions allow affected people to allege a State Party to the treaty does not comply with its legally binding obligations arising from the treaty. These MEAs are the 1998 Aarhus Convention on Information, Public Participation and Access to Justice ${ }^{26}$ and its 2003 Protocol on Pollutant Release and Transfer Registers, ${ }^{27}$ and the 1999 London Protocol on Water and Health. ${ }^{28}$

24 For detailed descriptions of the non-compliance procedures mentioned in this paper, see inter alia: Non-Compliance Procedures and Mechanisms and the Effectiveness of International Environmental Agreements (Tullio Treves, Attila Tanzi, Cesare Pitea, Chiara Ragni, \& Laura Pineschi eds., 2009).

25 See UNECE, http://www.unece.org.

26 Convention on Access to Information, Public Participation in Decision-making and Access to Justice in Environmental Matters, Aarhus, Denmark, Jun. 25, 1998. 2161 U.N.T.S. 447. The rules and procedures of the Compliance Committee of the Convention are established by Decision I/7, Review of Compliance, Oct. 21-23, 2002. U.N. Doc. ECE/MP.PP/2/Add.8.

27 Protocol on Pollutant Release and Transfer Registers to the Convention on Access to Information, Public Participation in Decision-Making and Access to Justice in Environmental Matters, Kyiv, Ukraine, May. 21, 2003. U.N. Doc. ECE/MP.PP/2003/1. The rules and procedures of the Compliance Committee for the review of compliance by the Parties with their obligations under the Protocol are established by Decision I/2, Review of Compliance, adopted in Geneva, Switzerland, Apr. 20-22, 2010. U.N. Doc. ECE/ MP.PRTR/2010/.

28 Protocol on Water and Health to the 1992 Convention on the Protection and Use of 
Other UNECE agreements only give individuals, or groupings of individuals, an indirect possibility of triggering a non-compliance procedure, such as the 1991 Espoo Convention on Environmental Impact Assessment ${ }^{29}$ and its 2003 Protocol on Strategic Environmental Assessment (SEA), ${ }^{30}$ and the 1992 Helsinki Convention on the Protection and Use of Transboundary Watercourses and International Lakes. ${ }^{31}$ Under the decisions of the COPs to these conventions, the public can activate a "committee initiative" by giving the secretariat of the concerned convention information on potential noncompliance situations. The secretariat can consider this information to be serious and solid enough to be transmitted to the Committee, who, in turn, can self-trigger a non-compliance procedure. ${ }^{32}$

Transboundary Watercourses and International Lakes, London, UK, Jun. 17, 1999. 2331 U.N.T.S. 202. The rules and procedures of the Compliance Committee are established by Decision I/2, Review of Compliance, adopted in Geneva, Switzerland, Jan. 17-19, 2007. U.N. Doc. ECE/MP.WH/2/Add.3.

29 Convention on Environmental Impact Assessment in a Transboundary Context, Espoo, Finland, Feb. 25, 1991. 1989 U.N.T.S. 309.

30 Protocol on Strategic Environmental Assessment to the Convention on Environmental Impact Assessment in a Transboundary Context, Kyiv, Ukraine, May 21, 2003. U.N. Doc. ECE/MP.EIA/2003/2.

31 Convention on the Protection and Use of Transboundary Watercourses and International Lakes, Helsinki, Finland, Mar. 17, 1992. 1936 U.N.T.S. 269.

32 As to the Helsinki Water Convention, the "Implementation Committee" was created recently by Decision VI/1, Decision VI/1, Support to implementation and compliance, U.N. Doc. ECE/MP.WAT/37/Add.2. The rules and procedures of the Espoo Convention Compliance Committee did not consider the possibility of the public's indirect access at first: see Decision II/4, Meeting of the Parties to the Convention on Environmental Impact Assessment in a Transboundary Context, Report of the Second Meeting, Aug. 7, 2001 U.N. Doc. ECE/ MP.EIA/4. It has been revised by Decision III/2, Review of Compliance, adopted in Cavtat, Croatia, on Jun. 1-4, 2004. U.N. Doc. MP.EIA/2004/3. (see in particular $\$ \$ 6-7$ of the Decision) and clarified by Annex IV to Decision IV/2, Operating rules of the Implementation Committee, adopted in Bucharest, Romania, on May. 19-21, 2008. U.N. Doc. ECE/ MP.EIA/2008/4. Decision I/ 6 adopted by the COP of the Espoo Convention serving as the Meeting of the Parties to the SEA Protocol at its first session has extended the Compliance Committee mandate, rules and procedures to the SEA Protocol: Decision I/6, Application of the compliance procedure of the Convention on Environmental Impact Assessment in a Transboundary Context to the Protocol on Strategic Environmental Assessment, adopted in 
Other than being created by COP decisions and not negotiated at the stage of treaty-making, direct access to these international remedies is acceptable to States because they are non-judicial. They do not aim at deciding on the legal responsibility of States, they are not based on the traditional "sanctioned prescription" approach. They are seen as incentives to comply and as a means of bringing States back to compliance. ${ }^{33}$ As regards the consequences of non-compliance procedures, they are usually soft, though some (such as the CITES', ${ }^{34}$ the Montreal Protocol's ${ }^{35}$ and the Kyoto Protocol' ${ }^{36}$ ) can result in sanctions, in the form of a suspension of the noncompliant party's eligibility to enjoy the benefits associated with the fact of being a party. However, these "harder" non-compliance procedures do not allow the public's direct or indirect access. Environmental non-compliance procedures that allow direct and indirect submissions from the public rely most frequently on the techniques of name and shame, and the provision of assistance when non-compliance arises from a lack of capacity. Soft consequences do not necessarily mean no, or little, impact on State parties: a compliance committee who finds that the breach stems from lacking, obsolete or inconsistent legislation of the concerned party can prompt the non-compliant party to create or re-write its legislation. ${ }^{37}$

Geneva, Switzerland, May. 21-23, 2011. U.N. Doc. ECE/MP.EIA/SEA/2.

33 Vertic, a Guide to Verification for Environmental Agreements 2 (2003); Sandrine Maljean-Dubois \& Vanessa Richard, Mechanisms for the Monitoring and Implementation. 9 Glob. Governance 4 (2004).

34 Convention on International Trade in Endangered Species of Wild Fauna and Flora, Washington, USA, Mar. 3, 1973. 983 U.N.T.S. 243.

35 Protocol on Substances that Deplete the Ozone Layer, Montréal, Canada, Sep. 16, 1987. 1552 UNTS 3.

36 Protocol to the United Nations Framework Convention on Climate Change, Kyoto, Japan, Dec. 11, 1997. 2303 UNTS 148.

37 See for example Vanessa Richard, Learning by doing. Les procédures de réaction au non-respect dans la Convention d'Espoo et son Protocole de Kiev, 3 Revue juridiQue de L'environnement 327 (2011). 


\subsection{International Legal Accountability Mechanisms for Environmental Damages Due to International Organizations}

The issue of international organizations' legal accountability for environmental damages forms a very different landscape than that described in respect to States. The activities of international organizations nowadays cover an impressive range of matters, from peace-keeping obligations to post-conflict administration, from development assistance to heath publicprivate partnerships. ${ }^{38}$ "[I]n aggregate [international institutions] regulate and manage vast sectors of economic and social life through specific decisions and rulemaking. ${ }^{~}{ }^{39}$ And yet, they are almost entirely immune to liability: they are immune unless they expressly agree not to be (and they hardly do). ${ }^{40}$ They are not parties to MEAs. ${ }^{41}$ They are bound by the terms of their constitutive instruments, that might provide for environmental protection directly or not. Inferring that it creates an obligation to justify their actions vis-à-vis affected people seems a long stretch. The nature and opposability of the rules of international organizations - i.e. acts adopted by international organizations'

38 See inter alia August Reinisch, Securing the Accountability of International Organizations, 7 Glob. Governance 131 (2001); Lisa Clarke, Responsibility of International Organizations under International Law for the Acts of Global Health Public-Private Partnerships, 12 CHI. J. InT'L L. 55 (2011); Joy Gordon, Accountability and Global Governance: The Case of Iraq, 20 Eтhics \& Lnt'L Aff. 79 (2006); Marten Zwanenburg, UN Peace Operations between Independence and Accountability, 5 InT'L ORg. L. Rev. 23 (2008).

39 Benedict Kingsbury, Nico Krisch \& Richard Stewart, The Emergence of Global Administrative Law, 68 L. \&Cont. Probs. 15, 17 (2005).

40 This article does not address contractual relations between international organisations and individuals (employment, call for tenders, relations with suppliers etc.)

41 For the purpose of this paper, the very specific situation of the European Union is voluntarily not dealt with. 
bodies "for internal consumption" $-{ }^{42}$ are debated. ${ }^{43}$ Put differently, there isn't any consensual answer to this question: is the law of international organizations international law that binds international organizations? The International Law Commission's Draft Articles on the Responsibility of International Organisations (DARIOs) doesn't solve the issue this article deals with. Draft Article 2b) specifies that "'rules of the organization' means, in particular, the constituent instruments, decisions, resolutions and other acts of the international organization adopted in accordance with those instruments, and established practice of the organization. ${ }^{244}$ Unless the lex specialis of the organization provides otherwise (DARIOs, Article 64), a breach of the rules of the organization amounts to an internationally wrongful act only if the rules "are part of international law" and, what is more, "while the rules of the organization may affect international obligations for the relations between an organization and its members, they cannot have a similar effect in relation to non-members. ${ }^{45}$ Besides, where would disputes be settled? ${ }^{46}$

42 "Droit à consommation interne," following the expression of Slim Laghmani, Droit international et droits internes: vers un renouveau du jus gentium?, in DrOIT INTERNATIONAL et droits internes. Développements récents 23, 34 (Rafâa Ben Achour and Slim Laghmani eds.,1999).

43 See the debates presented in Giorgio Gaja, Special Rapporteur, International Law Commission, Third Report on Responsibility of International Organizations, May. 13, 2005. U.N. Doc. A/CN.4/553, \$\$18-19.

44 International Law Commission, Draft articles on the responsibility of international organizations, with commentaries, in 2 Y. B. INT'L L Comm., Part Two (2011).

45 International Law Commission, Draft articles on the responsibility of international organizations, commentary of Article 5(3).

46 The Permanent Court of Arbitration offers the opportunity to resort to its Optional Rules for Arbitration to settle disputes between "an international organization and a party that is neither a State nor an international organization [who] have agreed in writing that disputes that may arise or that have arisen between them shall be referred to arbitration under the Permanent Court of Arbitration Optional Rules for Arbitration between International Organizations and Private Parties" (Article 1.1). To settle the dispute, "the arbitral tribunal shall have regard both to the rules of the organization concerned and to the law applicable to the agreement or relationship out of or in relation to which the dispute arises and, where 
International organizations therefore operate without having to give legal account to anyone for the impacts of their activities. ${ }^{47}$ Against all evidence that good intentions may sometimes result in negative impacts, that the choices made to solve a problem might not always be adequate and delay the adoption of more effective remedial measures, and that one disaster can delegitimize a whole institution that has otherwise done well: a potent myth remains that international organizations are inherently good guys who can do no harm. A French proverb says that hell is paved with good intentions. Given the terms of this particular mythology, it may not be surprising that the only kind of international organizations that have set up permanent legal accountability mechanisms are the "ugly ducklings" of the family, who have been exposed to severe criticism for years: multilateral development banks (MDBs).

MDBs who account through an international legal accountability mechanism are the World Bank Group, the African Development Bank Group (AfDB), the Asian Development Bank (ADB), the European Bank for Reconstruction and Development (EBRD), the European Investment Bank (EIB) and the Inter-American Development Bank (IDB). ${ }^{48}$ From a

appropriate, to the general principles governing the law of international organizations and to the rules of general international law." (Article 33) It is however difficult to conceive how individuals or groupings of individuals, affected by the negative impacts of an activity of an organisation implemented in a manner that is inconsistent with the organisation's internal rules, could obtain this organisation's agreement in writing to submit the dispute to arbitration, and could bear the costs of such procedure. See Permanent Court of Arbitration Optional Rules for Arbitration between International Organizations and Private Parties, Jul. 1, 1996, http://www.pca-cpa.org/showfile.asp?fil_id=292 (last visited 15 May 2013).

47 The present article does not address cases where criminal behaviour is alleged (for example, corruption) or what is denounced is the criminal behaviour of a particular employee (for example, the UN Refugee Agency (UNHCR) has created an investigation section of the Inspector General's Office, who is "responsible for receiving and looking into allegations of misconduct against UNHCR personnel." On the latter see: http://www.unhcr.org/ pages/49f0619f6.html (last visited 17 May 2013).

48 For comparative studies of MDBs' accountability mechanisms, see Richard E. Bissell \& Suresh Nanwani, Multilateral Development Bank Accountability Mechanisms: Developments 
legal accountability angle, the role of MDBs' grievance mechanisms is to assess, upon request of the people affected by the organization's activities, the compliance of the organization with its own internal rules, that is to say in broad terms with their policies and procedures for instance related to the disclosure of information, environmental and social assessment, indigenous peoples' rights, etc.

The World Bank Group has created two grievance mechanisms. The first, and also the first of its kind, is the Inspection Panel that addresses grievances arising from official development assistance provided by the International Bank for Reconstruction and Development (IBRD) and the International Development Association (IDA). It was created in 1993 and modified in 1996 and 1999. This independent body examines the requests emanating from people who allege they are or will be affected by a project which is financed by the BIRD or the IDA, and whose present or potential harm results from a breach, by these agencies' staff, of their operational policies and procedures. ${ }^{49}$ The second grievance mechanism is the independent Compliance-Advisor/Ombudsman (CAO) created in 1999. It addresses grievances arising from the activities of the International Finance Corporation (IFC) and the Multilateral Investment Guarantee Agency (MIGA), who both promote private sector investment in development. In its "Ombudsman" role, the CAO examines the complaints of currently or potentially project-affected people, whether the alleged harm stems from a breach of their internal rules by these agencies or not. However, in specific

and Challenges, 6 Manchester J. Int'L Econ. L. 2 (2009); Daniel Bradlow, Private Complainants and International Organizations: A Comparative Study of the Independent Inspection Mechanisms in International Financial Institutions, 36 Georgetown J. INT'L. L 403 (2005).

49 Operating Procedure of the Panel (August 19, 1994), http://go.worldbank.org/C6MIJ7MIP0 (permanent URL). See also Res. BIRD 93-10 and AID 93-6 creating the Panel, 22 September 1993; Review of the Resolution, 17 October 1996; Clarification of the Second Review (April 20, 1999), http://go.worldbank.org/NN6UOKNBZ0 (permanent URL). 
sensitive cases, the CAO might shift from its "Ombudsman" mission to its "Compliance" mission, and issue in addition an audit of the compliance of the IFC/MIGA with its procedures and policies. ${ }^{50}$ The brand new (March 2013) version of the CAO Operating Guidelines inter alia clarifies the vocabulary, "Ombudsman" function being replaced by "dispute resolution" function and "compliance audit" by "compliance investigation." 51

The accountability of the Asian Development Bank can be examined by the Inspection Committee created in 1995-1996 and replaced by an Accountability Mechanism in 2003. This Accountability Mechanism was revised in May 2012 and includes a Special Project Facilitator (SPF) that acts as a mediation forum where project-affected people can file their complaints whether the ADB's operational policies and procedures are breached or not, and; a Compliance Review Panel (CPR), that examines complaints based on an alleged breach of the ADB's policies and procedures. The 2012 review process dropped the requirement that affected people must start with the consultation process before they can file for a compliance review. ${ }^{52}$

The European Bank for Reconstruction and Development created in 2003 an Independent Recourse Mechanism ("IRM”). It was replaced in 2010 by the "Project Complaint Mechanism," which has both a compliance review mission and a problem-solving function, depending on whether the complaint is assessed as eligible for a compliance review, or a problem-solving initiative, or both. Civil society organizations can only request a compliance review. ${ }^{53}$

50 CAO Operational Guidelines (June 8, 2007), http://www.cao-ombudsman.org/about/ whoweare/documents/EnglishCAOGuidelines06.08.07Web.pdf (last visited 18 May 2013)

51 CAO Operational Guidelines (March, 2013), http://www.cao-ombudsman.org/howwework/ documents/CAOOperationalGuidelines_2013.pdf(last visited 18 May 2013)

52 Accountability Mechanism Policy 2012 (May 24, 2012), http://www.adb.org/site/ accountability-mechanism/ (last visited 15 May 2013).

53 Project Complaint Mechanism: Rules of Procedure (May 16, 2009), http://www.ebrd.com/ pages/project/pcm.shtml (last visited 15 May 2013). 
As regards the Inter-American Development Bank, in 2010 the Independent Consultation and Investigation Mechanism (MICI, for Mecanismo Independiente de Consulta e Investigación) succeeded the Independent Inspection Mechanism created in 1994. It works on a twostage basis, with a consultation phase that, if unsuccessful, can precede a compliance review phase. $^{54}$

In the framework of the African Development Bank, the Independent Review Mechanism entrusted to a Compliance Review and Mediation Unit ("CRMU") was set up in 2004 and modified in 2010. Like the EBRD mechanism, it has a twofold (problem-solving/compliance review) structure and can lead to a compliance review, a problem-solving initiative, or both. ${ }^{55}$

Finally, the Complaints Mechanism of the European Investment Bank was created in 2008 and revised in 2010. It offers the possibility to access mediation, or compliance control, or mediation followed by compliance control if mediation is unsuccessful. The grievance mechanism has an additional procedural level that consists in the possibility of an appeal before the European Ombudsman if requesters are not satisfied with the EIB Complaints Mechanism's findings. ${ }^{56}$

Such mechanisms do not record wrongful acts under international law that would be attributable to these organizations, they do not decide on a responsibility based on the lex specialis of the bank, and they are not intended as judicial. Their core feature is that accountability is not focused on the breach of an international rule but on actual or potential harm. This explains

54 Politica de constitución del Mecanismo Independiente de Consulta e Investigación (February 17, 2010), http://www.iadb.org/en/mici/(last visited 15 May 2013).

55 Independent Review Mechanism, Operating Rules and Procedures (June 16, 2010), http://www. afdb.org/en/about-us/structure/independent-review-mechanism-irm/ (last visited 15 May 2013).

56 Complaints Mechanism Principles, Terms of Reference and Rules of Procedure (February, 2010), http://www.eib.org/attachments/strategies/complaints_mechanism_policy_en.pdf (last visited 18 February 2014). 
why, except for the Inspection Panel, every accountability mechanism is combined with a problem-solving procedure. Besides, eligibility to access these problem-solving (consultation, mediation, etc.) procedures does not necessarily depend on the fact claimants allege a breach of the organization's rules. In the framework of the $\mathrm{IDB}^{57}$ and $\mathrm{AfDB}^{58}$ grievance mechanisms, mediation requests must specify how actual or potential harm results from an act or omission of the organization that breaches its operational policies and procedures. The $\mathrm{CAO},{ }^{59}$ the ADB Accountability Mechanism ${ }^{60}$ and the EBRD Project Complaint Mechanism ${ }^{61}$ do not require this when the problem-solving procedure is sought after. Claimants are only required to describe why, in their view, the development project has created or is likely to create negative impacts that affect or will affect them. The EIB Complaints Mechanism requires that requests concern alleged maladministration of the EIB in its actions and/or omissions. ${ }^{62}$ When a bank is found non-compliant, it does not result in its legal implication or compensation for the victims. The bank is expected to adopt corrective measures.

What matters, then, is not so much whether the MDB has not complied with its own internal rules as whether it originated negative impacts, not so much compliance with the letter of the rules of the organization as respect for the organization's overarching objective (development assistance to create better living conditions). More prosaically, the legal accountability dimension is not the finality of MDBs' grievance mechanisms. It is one way of correcting development projects so that they can be implemented with as little negative impacts as possible. Their creation was motivated less by

57 Política de constitución del Mecanismo Independiente de Consulta e Investigación, $\$ 40$ f).

58 Independent Review Mechanism, Operating Rules and Procedures, $₫ 5 \mathrm{c}$ ) and d).

59 CAO Operational Guidelines, $\$ 2.2 .1$ (formerly $\$ 2.2 .2$. in the 2007 version).

60 Accountability Mechanism Policy, $\$ 141$ (2012).

61 Project Complaint Mechanism: Rules of Procedure, $\$ 10$ e) a contrario.

62 Complaints Mechanism Principles, Terms of Reference and Rules of Procedure, $\$ 3.1$. 
the promotion of the rule of law within the organization than by concerns regarding the organization's legitimacy and concerns over the balance of power among the bank's bodies. ${ }^{63}$

\subsection{International legal accountability mechanisms for environmental damages due to businesses}

The third category of actors that can be requested to render account in the eyes of international standards are multinational enterprises (MNE). What comes immediately to mind is that enterprises are not subjects of international law. Except when it comes to giving rights to enterprises, so as to protect transnational investment, international law more or less ignores them. States have, so far, shunned the idea of establishing common behavior standards they would all impose on enterprises under their jurisdiction. Apart from situations when the liability of enterprises is expressly provided for by treaties ${ }^{64}$ the hold of international law on these transnational actors-whose activities can unquestionably have an important impact in the countries where they operate - is growing, but remains fragile and mediate. ${ }^{65}$ If needs be, remedies are considered to be available at domestic level. However, access to effective remedies is quite diverse depending on the country, and often very limited ${ }^{66}$ Political decision-makers are subject to economic and political

63 Maartje van Putten, a former member of the Inspection Panel, gives a fascinating account of this latter aspect: Maartje van Putten, Policing the Banks: Accountability Mechanisms for the Financial Sector (2008).

64 As, for instance, by the International Convention on Civil Liability for Oil Pollution Damage, Nov. 22, 1969. 973 U.N.T.S. I-14097.

65 See inter alia Elisa Morgera, Corporate Accountability in International Environmental Law (2009); Sandrine Maljean-Dubois \& Vanessa Richard, The Applicability of International Environmental Law to Private Enterprises, in $\mathrm{H}_{\mathrm{ARN}} \mathrm{N}$ SSING Foreign Investment to Promote Environmental Protection: Incentives and SAfeguards 69 (Pierre-Marie Dupuy \& Jorge E. Viñuales eds., 2013).

66 Natalie Bridgeman \& David Hunter, Narrowing the Accountability Gap: Toward a New Foreign Investor Accountability Mechanism, 20 Geo. Int'L EnVtL. L. Rev. 195 (2008); 
pressures. States do not have comparable capacities and do not offer the same level of control of environmental norms, for lack of technical or financial means, or else of skilled personnel. Nor do they all have judicial mechanisms that are at once accessible, reliable and impartial. The State is sometimes able to hear a case arising from a breach of international law that occurred in another country, using the nationality connection as a ground for jurisdiction, but this situation remains very limited. ${ }^{67}$ Let us add to this list of factors with the fact that available domestic remedies are not always well-suited to the complexity of relations between main branches and subsidiaries, supply chains and so on.

As States cannot be bypassed and are not willing to enter into legally binding obligations in this respect for fear of negative economic consequences, the 2003 "Norms on the responsibilities of transnational corporations and other business enterprises with regard to human rights," elaborated by the UN Sub-commission on the promotion and protection of human rights, "encountered a frosty reception from member states already primed with the concerns of the corporate sector." ${ }^{\prime 68}$ The Norms provided that

Transnational corporations and other business enterprises shall carry out their activities in accordance with national laws, regulations, administrative practices, and policies relating to the preservation of the environment of the countries in which they operate, as well as in accordance with relevant international agreements, principles, objectives, responsibilities, and standards

M. Francheteau-Laronze, L'Application du droit international de l'environnement par le juge national: éléments d'analyse comparative, in Implementation of International Environmental Law 607 (Sandrine Maljean-Dubois \& Rajamani eds., 2012).

67 On the Alien Tort Claims Act see in particular Elisa Morgera, supra note 65, at123-33; Natalie Bridgeman, Human Rights Litigation Under the ATCA as a Proxy For Environmental Claims, 6 Yale Hum. Rts. Dev. L.J. 1 (2003).

68 David Kinley and Rachel Chambers, The UN Human Rights Norms for Corporations: The Private Implications of Public International Law, 6 Hum. RTs. L. Rev. 447, 449 (2006). 
with regard to the environment as well as human rights, public health and safety, bioethics and the precautionary principle, and shall generally conduct their activities in a manner contributing to the wider goal of sustainable development. ${ }^{69}$

In addition, the Norms required that

transnational corporations and other business enterprises shall be subject to periodic monitoring and verification by United Nations, other international and national mechanisms already in existence or yet to be created, regarding application of the Norms. This monitoring shall be transparent and independent and take into account input from stakeholders (including non-governmental organizations) and as a result of complaints of violations of these Norms. $^{70}$

By contrast, the well-accepted Guiding Principles (often referred to as the "Protect, Respect and Remedy" framework) fleshed out by John Ruggie, the UN Secretary General's Special Representative for Business and Human Rights, specifies that "[n]othing in these Guiding Principles should be read as creating new international law obligations." ${ }^{, 71}$ As for the Global Compact, a set of principles that enterprises are invited to adhere to and implement, it includes three principles related to the protection of the environment, ${ }^{72}$ but one can doubt it is likely to generate sensible and widespread improvements.

69 Sub-commission on the Promotion and Protection of Human Rights, Norms on the Responsibilities of Transnational Corporations and other Business Enterprises with Regard to Human Rights, Aug. 13, 2003. U.N. Doc. E/CN. 4/Sub.2/2003/12/Rev.226, \$14.

70 Norms on the Responsibilities of Transnational Corporations, $\$ 16$.

71 Report of the Special Representative of the Secretary-General on the issue of human rights and transnational corporations and other business enterprises, John Ruggie, Guiding Principles on Business and Human Rights: Implementing the United Nations 'Protect, Respect and Remedy' Framework, Mar. 21, 2011. U.N. Doc. A/HRC/17/31.

72 "Businesses should support a precautionary approach to environmental challenges" (principle 
There is, however, one international mechanism that allows affected people to directly ask a MNE to account for its behavior in the eyes of internationally-defined standards: the specific grievance mechanism provided by the Guidelines for Multinational Enterprises set up by the Organisation for Economic Cooperation and Development (OECD). The OECD Guidelines are not a set of internal policies of the organization. They are recommendations addressed by governments to multinational enterprises operating in and from their territories, aiming to ensure that multinational enterprises adopt a socially and environmentally responsible attitude. The latest version of the Guidelines was issued in May 2011 and, in particular, introduces new recommendations on human rights, in addition to various recommendations regarding working conditions and the protection of the environment that already existed. ${ }^{73}$ Principles related to the protection of the environment include compliance with domestic environmental laws and regulations, consideration for "relevant international agreements, principles, objectives, and standards," contribution to the wider goal of sustainable development, setup and implementation of environmental management systems, impact assessment, information and consultation of the public and workers and so on. ${ }^{74}$

Formally, countries who adhere to the Guidelines make a binding commitment to implement them, in accordance with the Declaration on

7), undertake initiatives to promote greater environmental responsibility (principle 8), and "encourage the development and diffusion of environmentally friendly technologies" (principle 9): United Nations Global Compact, 26 July 2000, http://www.unglobalcompact. org/.

73 Environmental considerations appeared in the 1991 review that followed the Bhopal disaster: Elisa Morgera, An Environmental Outlook on the OECD Guidelines for Multinational Enterprises: Comparative Advantage, Legitimacy, and Outstanding Questions in the Lead up to the 2006 Review, 18 Geo. Int'L EnvtL. L. Rev. 751 (2006).

74 See Part VI, "Environment" of the Guidelines, OECD Guidelines for Multinational Enterprises 2011 Edition, 25 May 2011, pp. 42-44, http://dx.doi. org/10.1787/9789264115415-en (permanent URL). 
International Investment and Multinational Enterprises and the decisions of the OECD Council that underpin the Declaration. ${ }^{75}$ In addition to the commitment of OECD member countries under the Council's decision, non-member countries can voluntarily adhere to the Guidelines. To date, ${ }^{76}$ the 34 members of the OECD have been joined by 12 nonmembers (Argentina, Brazil, Colombia, Costa Rica, Egypt, Jordan, Latvia, Lithuania, Morocco, Peru, Romania and Tunisia) and 2 other countries (Serbia and Ukraine) have requested to adhere. ${ }^{77}$ Adhering governments commit to addressing the recommendations of the OECD Guidelines to multinational enterprises, but multinational enterprises' compliance with the Guidelines is voluntary and non-binding. Though voluntary and nonbinding for multinational enterprises, the Guidelines are complemented by Implementation Procedures ${ }^{78}$ under which adhering governments set up National Contact Points (NCPs). States are free to choose the form they want to give to their NCPs and the Guidelines are scarcely prescriptive on their degree of independence: they "must be composed and organised such that they provide an effective basis for dealing with the broad range of issues covered by the Guidelines and enable the NCP to operate in an impartial manner while maintaining an adequate level of accountability to the adhering government." ${ }^{, 79}$ NCPs can examine "specific instances" relating

75 OECD Declaration on International Investment and Multinational Enterprises, http://www.oecd.org/daf/inv/investment-policy/ oecddeclarationoninternationalinvestmentandmultinationalenterprises.htm (last visited 17 May 2013). The first version of the Declaration was adopted on 21 June 1976. It has been reviewed 5 times. The latest version was adopted 25 May 2011.

76 February 2014.

77 OECD, OECD Guidelines for Multinational Enterprises, Update 2011
May. 3, 2011. C (2011)59.

78 Latest version: Amendment of the Decision of the Council on the OECD Guidelines for Multinational Enterprises, Part II of the OECD Guidelines for Multinational Enterprises 2011 Edition.

79 OECD, OECD Guidelines for Multinational Enterprises 71 (2011). 
to the implementation of the Guidelines raised by the "business community, worker organisations, other non-governmental organisations and other interested parties." ${ }^{\prime 80}$ Their assessment can result in issuing recommendations. In other words, the compliance of multinational enterprises operating in or from adhering countries territories with the Guidelines is voluntary, but can be challenged by any concerned party before a NCP. NCPs and the specific instances mechanism are intended to offer a mediation and conciliation platform for resolving practical issues that may arise and not to act as a judicial procedure or decide sanctions.

One of the main strengths of the OECD Guidelines is that they are quite flexible and realistic on the variety of enterprises, activities and relationships between enterprises and can adapt to very varied situations: "A precise definition of multinational enterprises is not required for the purposes of the Guidelines. These enterprises operate in all sectors of the economy. They usually comprise companies or other entities established in more than one country and so linked that they may coordinate their operations in various ways. While one or more of these entities may be able to exercise a significant influence over the activities of others, their degree of autonomy within the enterprise may vary widely from one multinational enterprise to another. Ownership may be private, State or mixed. The Guidelines are addressed to all the entities within the multinational enterprise (parent companies and/ or local entities). According to the actual distribution of responsibilities among them, the different entities are expected to co-operate and to assist one another to facilitate observance of the Guidelines. ${ }^{~} 81$ Heated debates about the extent to which a main branch may be held accountable for the behavior of its subsidiaries or suppliers, or else a private bank may be held accountable for the behavior of the customers it lends money to, led the Committee on

$80 I d$, at 72 .

$81 I d$, at $17-18$. 
International Investment and Multinational Enterprises (CIME) of the OECD to deliver an interpretation of the Guidelines in 2003. In its statement, the CIME considers that their application "rests on the presence of an investment nexus" and that the Guidelines "link the issue of scope to the practical ability of enterprises to influence the conduct of their business partners with whom they have an investment like relationship. ${ }^{.82}$ Unsurprisingly, NCPs' practice on this point is inconsistent. ${ }^{83}$

It is very interesting that NCPs are competent to hear grievances related to activities operated in non-adhering countries provided that the implicated MNE is based on the territory of an adhering country. For example, a French MNE can be subject to a specific instance before the French NCP for the activities of a subsidiary in Mozambique, who is not an adhering country. Besides, because of their multinational character and the variety of possible structures, nothing forbids the triggering of several specific instances in NCPs of several adhering countries with respect to a same situation. This might be the case when the alleged breach of the Guidelines relates to the activities of several businesses with different nationalities and who share the ownership of a local society, the behavior of whom is denounced.$^{84}$ Likewise, nothing forbids submitting a specific instance arising from a single situation both to the NCP that is appropriate with regard to the nationality of a main branch and to the NCP that is appropriate with regard to the nationality of a

82 OECD Guidelines for Multinational Enterprises: 2003 Annual Meeting of the National Contact Points 12, Report by the Chair, 23-24 June 2003,, http://www.oecd.org/daf/inv/ mne/15941397.pdf (last visited 18 May 2013).

83 Sarah Fick Vendzules, The Struggle for Legitimacy in Environmental Standards Systems: The OECD Guidelines for Multilateral Enterprises 21 Colo. J. Int'L Envtl. L. \& Pol’y 451 (2010).

84 See for example the specific instance submitted by several NGOs to the French, Belgian and Luxemburg NCPs against the firms Bolloré (France), Financière du Champ de Mars (Belgium), SOCFINAL and Intercultures (Luxemburg), who own SOCAPALM, the biggest palm oil producer in Cameroon: Sherpa, 'Des palmiers et des hommes: comment la SOCAPALM viole les droits sociaux et environnementaux des communautés locales', Dec. 7 , 2010, http://www.asso-sherpa.org/archives/1165 (last visited 19 May 2013). 
subsidiary. ${ }^{85}$ When different NCPs address a same single situation and one of them considers the grievance to be solid enough to require an examination, the latter consults the $\mathrm{NCP}(\mathrm{s})$ of the other country or countries concerned. ${ }^{86}$

By and large, the practice of NCPs regarding the application and interpretation of the Guidelines is too heterogenic to generate "legal" certainty. Essentially based on the name and shame effect, the lack of binding consequences and even when a MNE can be considered to be a "habitual offender," considerably weakens the accountability allowed by NCPs. ${ }^{87}$ Unless a hardening of the Guidelines is operated in domestic law, as in Norway, ${ }^{88}$ or some significant sensation in the media ${ }^{89}$ is orchestrated in particular through powerful advocacy NGO campaigns, the accountability effect of the specific instances procedure seems much weaker than it could have been.

85 As was the case concerning the activities of the Shell Capsa refinery, in Argentina, that gave rise to the submission of a specific instance both to the Argentinian NCP and to the Dutch NCP: Joris Oldenziel, Joseph Wilde-Ramsing \& Patricia Feeney, OECDWatch, 10 Years On: Assessing the contribution of the OECD Guidelines for Multinational Enterprises to Responsible Business Conduct 46 (2010), http://oecdwatch.org/publications-en/Publication_3550/ (last visited Feb. 5, 2014).

86 Item C (2)(b) of Procedural Guidance, supra note 74, at 71.

87 Gefion Schuler, Effective Governance through Decentralized Soft Implementation: The OECD Guidelines for Multinational Enterprises 9 GER. L. J. 1755, pp. 1756-1757 (2008); Oldenziel, Wilde-Ramsing \& Feeney, supra note 85.

88 OECD, Annual Report on the OECD Guidelines for Multinational Enterprises 2010. Corporate Responsibility: Reinforcing a Unique Instrument 15 (2010).

89 Like in the Australia and New Zealand Banking Group case: Oldenziel, Wilde-Ramsing \& Feeney, supra note 85, at 18, 28-29. 


\section{Main Differences between International Legal Accountability for Environmental Damages and International Responsibility}

Looking back at the three constitutive elements of an accountability mechanism - a set of operative standards, a mechanism that brings together accountable entities and account-holders, and the mechanism's capacity to assess and draw consequences - a number of significant differences with responsibility mechanisms emerge.

Though the central feature of accountability mechanisms is to be tailored to the specifics of a category of actors and their activities, answering the question "who is accountable?" can be trickier than expected, or at least requires entering into more details than expected in the case of international organizations and multinational enterprises. As mentioned above, the specific instance procedure of the OECD Guidelines has a very wide potential reach, because it allows taking account of the reality of the industrial command chain, of the location of control and influence, regardless of the legal nature of the relationships. The case of multinational banks' accountability mechanisms is also worth pondering, since they can have interesting ripple effects.

Banks finance the activities of others, and direct accountability of banks is likely to indirectly result in the accountability of borrowers. If an accountability mechanism finds that a MDB has not complied with its policies related to the protection of the environment - for example because it has validated the environmental impact assessment made by the borrowing State, whereas it was incomplete with regard to the requirements of the bank - then the accountability mechanism can have an indirect consequence on the borrowing state, who will be required to deliver additional data so that the bank can validly give a green light to the decision to lend. Likewise, if a 
MDB funds or guarantees a private investment project that has environmental impacts, even in situations where what is requested is not a compliance review but a problem-solving procedure, the accountability process is likely to have an impact on the private investor. It can result in delays for private businesses and a strong incentive to conduct consultations. Beyond, it can help private businesses acquire a better understanding of the impact of their activities and of how to handle their relationships with affected people.

As for account-holders, accountability mechanisms allow a much broader access than the one allowed by international tribunals, firstly and obviously because they are not intrinsically restricted to international law subjects. The small number of accountability mechanisms based on environmental multilateral agreements that are open to public submission nevertheless shows that States are reluctant to depart from purely intergovernmental forms of cooperation, monitoring, and control. In the case of MDBs' accountability mechanisms, emphasis is clearly put on present or future harm. When not considered irrelevant to decide on a request's eligibility, wrongful acts under applicable standards are generally left in the background. Such an approach of eligibility substantially differs from the conditions that must be combined in order to trigger legal responsibility. Eligibility in the framework of the OECD Guidelines has evolved over the years, taking note of the evolution of social preoccupations and of the changing patterns of external pressure. The eligibility of NGOs to submit specific instances was included in the 2000 review that elusively stated that specific instances could be raised by the "business community, employee organisations and other parties concerned." 90 The 2011 version of the Implementation Procedures explicitly mentions NGOs as being eligible.

90 OECD, OECD Guidelines for Multinational Enterprises (2000). Procedural Guidance, Preamble of item IC): See OECD, OECD Guidelines for Multinational Enterprises (2011). Comparative table of changes made to the 2000 text, 2012, http://www.oecd.org/daf/inv/ mne/49744860.pdf (last visited 19 May 2013). Also, Oldenziel, Wilde-Ramsing \& Feeney, 
Differences are also obvious regarding applicable international standards. Treaty-based mechanisms operate in their own ecosystem. Thus, they are able to assess the consistency of a behavior not only with binding international law (the treaty in the framework of which the accountability mechanism operates), but also in the eyes of derived law adopted by treaty bodies. This derived law is far more precise and able to adapt to learned lessons than multilateral treaties, allowing the reflexive management of environmental cooperation issues.

Standards that apply to MDBs are chosen by each MDB itself. Operational policies and procedures of development banks are far from being impervious to the state and the development of international law, but they do not apply it as such. ${ }^{91}$ MDBs can even be the standard-setters on issues that international law does not consider. The World Bank's operational policy on environmental impact assessment has inspired the rules of a number of States and multilateral organizations, while the International Court of Justice, though recognizing the customary nature of the obligation to perform environmental impact assessments, considers that international law does not specify the content and scope of this obligation and leaves States the opportunity to define scope and content. ${ }^{92}$

As far as made-to-measure standards are concerned, the OECD Guidelines are the most creative. They are a unique blend of inspirations drawn from a wide array of instruments, from hard law to private standards. Since 1976, they have progressively incorporated environmental, human

supra note 85 , at 5-6.

91 The World Bank states for example that its "safeguard policies reflect the principles of international and regional environmental agreements signed by client countries": World Bank, Making Sustainable Commitments. An Environment Strategy for the World Bank (2001) http://go.worldbank.org/FG6N5KLXP0 (permanent URL). For further details, see Vanessa Richard, L'accountability comme alternative à la responsabilité? Réflexions en droit international de l'environnement, in Droit, sciences et techniques, Quelles Responsabilités? 523 (Etienne Vergès ed., 2011).

92 ICJ, Pulp Mills on the River Uruguay (Arg. v. Uru.), Apr. 20, 2010. 2010 I.C.J. 14, \$ 205. 
rights and social concerns. The 2001 version has included principles stemming inter alia from the Rio Declaration, the Aarhus Convention on access to information, public participation and access to justice in environmental matters, and the ISO 14000 "family" of standards. ${ }^{93}$ The latest version (May 2011) draws additional inspiration from a variety of more recent instruments, such as the Global Compact, the ISO 26000 guidance, the 2006 Policy and Performance Standards on Social and Environmental Sustainability of the IFC, the Equator Principles, Special Representative John Ruggie's works on Business and Human Rights, the UN Convention on Climate Change, the ADEME Bilan Carbone, the Greenhouse Gas Protocol Initiative, etc. ${ }^{94}$ It is a remarkable example of hybridization.

Finally, the consequences of international legal accountability mechanisms differ from those of responsibility. As mentioned above, none of them creates or includes a right to compensation. What they offer to victims of environmental damages is an opportunity to provoke the adoption of corrective measures. They do not decide on responsibility, but aim at identifying weaknesses and facilitating practical solutions. International legal accountability as understood in this contribution should therefore not be considered as a substitute for responsibility. Legal accountability and legal responsibility do not serve the same purpose and do not result in comparable solutions. None is, per se, better than the other, none can replace the other. It would be a mistake to despise the role of one or the other on the grounds of principle, either based on a largely fantasied purity of international law, or on largely-fantasied better new governance. All in all, they coexist quite interestingly.

93 Commentary of the OECD Guidelines for Multinational Enterprises, 2000 Edition, $\$ 30$. The Commentary specifies that "the fact that the Guidelines are addressed to enterprises means that no existing instrument is completely adequate for expressing this recommendation. The Guidelines therefore draw upon, but do not completely mirror, any existing instrument”: $\$ 38$.

94 OECD, OECD Guidelines for Multinational Enterprises (2011), note by the secretariat, at 8. 


\section{Reference}

Abbott, K. W. \& Snidal, D. (2009). Strengthening international regulation through transnational new governance: Overcoming the orchestration deficit. Vanderbilt Journal of Transnational Law, 42, 501-578.

African Development Bank Group. (2010). Independent review mechanism operating rules and procedures, 16 June 2010, Retrieved from http://www.afdb.org/en/about-us/structure/independent-reviewmechanism-irm/

Asian Development Bank. (2012). Accountability mechanism policy 2012. Retrieved from http://www.adb.org/site/accountabilitymechanism/

Bissell, R. E. \& Nanwani, S. (2009). Multilateral development bank accountability mechanisms: Developments and challenges. Manchester Journal of International Economic Law, 6(1), 2-55.

Bovens, M. (2007). Analysing and assessing accountability: A conceptual framework. European Law Journal, 13(4), 447-468.

Bradlow, D. D. (2005). Private complainants and international organizations: A comparative study of the independent inspection mechanisms in international financial institutions. Georgetown Journal of International Law, 36, 403-491.

Bridgeman, N. L. \& Hunter, D. B. (2008). Narrowing the accountability gap: Toward a new foreign investor accountability mechanism. Georgetown International Environmental Law Review, 20, 195205.

Bridgeman, N. L. (2003). Human rights litigation under the atca as a proxy for environmental claims. Yale Human Rights and Development Law Journal, 6, 1-43. 
Brunnée, J. (2002). COPing with consent: Law-making under multilateral environmental agreements. Leiden Journal of International Law, $1(1), 1-52$.

Brunnée, J. (2005). International legal accountability through the lens of the law of state responsibility. Netherlands Yearbook of International Law, 36, 3-38.

Churchill, R. R. \& Ulfstein, G. (2000). Autonomous institutional arrangements in multilateral environmental agreements: A littlenoticed phenomenon in international law. American Journal of International Law, 94(4), 623-659.

Clarke, L. (2001). Responsibility of international organizations under international law for the acts of global health public-private partnerships. Chicago Journal of International Law, 12(1), 55-85.

Dekker, I. F. (2005). Making sense of accountability in international institutional law. An analysis of the final report of the ILA committee on accountability of international organizations from a conceptual legal perspective. Netherlands Yearbook of International Law, 36(1), 83-118.

Domingo, R. (2010). The new global law. Cambridge, UK: Cambridge University Press.

Dupuy, P.-M. (1998). À propos des mésaventures de la responsabilité internationale des États dans ses rapports avec la protection de l'environnement. In Prieur, M. (Ed.), Les hommes et l'environnement, En hommage à A. Kiss (pp. 269-282). Paris, FR: Frison Roche.

Dupuy, P.-M. (2001). Libre parcours à travers la richesse d'une œuvre : notes de lecture sur les travaux de G. Abi-Saab. In Boisson de Chazournes, L. \& Gowland-Debbas, V. (Eds.), The international 
legal system in quest of equity and universality (pp. 9-20). The Hague, NL: Kluwer Law International.

European Bank for Reconstruction and Development. (2009). Project complaint mechanism: Rules of procedure, 16 May 2009. Retrieved from http://www.ebrd.com/pages/project/pcm.shtml European Investment Bank. (2010). Complaints mechanism principles, terms of reference and rules of procedure, February 2010. Retrieved from http://www.eib.org/attachments/strategies/complaints_ mechanism_policy_en.pdf

Francheteau-Laronze, M. (2011) L'Application du droit international de l'environnement par le juge national : éléments d'analyse comparative. In Maljean-Dubois, S. \& Rajamani, L. Implementation of international environmental law (pp. 607-52). Leiden, NL: Brill.

Gaja, G. (2005). International law commission third report on responsibility of international organizations, May. 13, 2005. U.N. Doc. A/ CN.4/553.

Gordon, J. (2006). Accountability and global governance: The case of iraq. Ethics \& International Affairs, 20(1), 79-98.

Grant, R. W. \& Keohane, R. O. (2005). Accountability and abuses of power in world politics. American Political Science Review, 99(1), 29-43.

Inter-american Development Bank. (2010). Política de constitución del Mecanismo Independiente de Consulta e Investigación, 17 February 2010. Retrieved from http://www.iadb.org/en/mici/.

International Law Association. (2004). Accountability of International Organisations, Final Report, Berlin Conference. Retrieved from http://tinyurl.com/ba3h78r.

International Law Commission. (2011). Yearbook of the International Law Commission, 2011, (vol. II, Part Two). New York, NY: United Nations Publications. 
Kingsbury, B., Krisch, N., \& Stewart, R. B. (2005). The emergence of global administrative law. Law \& Contemporary Problems, $68(3 \& 4), 15-$ 61.

Kinley, D. \& Chambers, R. (2006). The UN human rights norms for corporations: The private implications of public international law. Human Rights Law Review, 6, 447-497.

Koh, H. H. (1996). Transnational legal process. Nebraska Law Review, 75, 181-207.

Laghmani, S. (1999). Droit international et droits internes : vers un renouveau du jus gentium ?. In Ben Achour, R. \& Laghmani, S. (Eds.). Droit international et droits internes. Développements récents (pp. 2344). Paris, FR: Pedone.

Maljean-Dubois, S. \& Richard, V. (2013). The Applicability of International Environmental Law to Private Enterprises. In Dupuy, P.M. \& Vinuales, J. E. (Eds.). Harnessing Foreign Investment to Promote Environmental Protection: Incentives and Safeguards (pp. 69-96). Cambridge, UK: Cambridge University Press.

Maljean-Dubois, S. \& Rajamani, L. (Eds.). (2011). Implementation of international environmental law / La mise en œuvre du droit de l'environnement. The Hague, NL: Martinus Nijhoff.

Maljean-Dubois, S. \& Richard, V. (2004). Mechanisms for the monitoring and implementation of international environmental protection agreements. In IDDRI Working Paper Series 09/2004. Paris, FR: IDDRI. Retrieved from http://www.iddri.org/Publications/ Collections/Idees-pour-le-debat/id_0409_maljeandubois.pdf.

Maljean-Dubois, S.(2010). Les organes de contrôle du respect des dispositions internationales. In Jadot, B. (Ed.), Acteurs et outils du droit de l'environnement: développements récents, 
développements (peut-être) à venir (pp. 249-278). Brussels, BE: Anthémis.

Morgera, E. (2006). An environmental outlook on the OECD guidelines for multinational enterprises: Comparative advantage, legitimacy, and outstanding questions in the lead up to the 2006 review. Georgetown International Environmental Law Review, 18(2), 751777.

Morgera, E. (2009). Corporate accountability in international environmental law. Oxford, UK: Oxford University Press.

Mulgan, R. (2003). Holding power to account: accountability in modern democracies. London, UK: Palgrave Macmillan.

Organisation for Economic Co-operation and Development. (2003). OECD guidelines for multinational enterprises: 2003 annual meeting of the national contact points. Report by the Chair, 23-24 June 2003. Retrieved from http://www.oecd.org/daf/inv/mne/15941397.pdf

Organisation for Economic Co-operation and Development. (2010). Annual report on the OECD guidelines for multinational enterprises 2010. corporate responsibility: Reinforcing a unique instrument. Paris, FR: OECD.

Organisation for Economic Co-operation and Development. (2011). OECD guidelines for multinational enterprises, update 2011, note by the secretariat, May. 3, 2011. C (2011)59.

Organisation for Economic Co-operation and Development. (2000). OECD guidelines for multinational enterprises, 2000 edition. Paris, FR: OECD Publishing.

Oldenziel, J., Wilde-Ramsing, J. \& Feeney, P. (2010). OECD watch - 10 years on. Retrieved from http://oecdwatch.org/publications-en/ Publication_3550/ 
Protocol on pollutant release and transfer registers to the convention on access to information, public participation in decision-making and access to justice in environmental matters, May 21, 2003. U.N. Doc. ECE/MP.PP/2003/1.

Protocol on strategic environmental assessment to the convention on environmental impact assessment in a transboundary context, May 21, 2003. U.N. Doc. ECE/MP.EIA/2003/2.

Protocol on water and health to the 1992 convention on the protection and use of transboundary watercourses and international lakes, Jun. 17, 1999. 2331 U.N.T.S. 202.

Putten, M.V. (2008). Policing the banks. Accountability mechanisms for the financial sector. Montréal, CA: McGill-Queen's University Press.

Raustalia, K. (2000). Compliance and effectiveness in international regulatory cooperation. Case Western Reserve Journal of International Law, 32, 387-398.

Reinisch, A. (2001). Securing the accountability of international organizations. Global Governance, 7(2), 131-149.

Richard, V. (2011). L'accountability comme alternative à la responsabilité ? Réflexions en droit international de l'environnement. In Vergès, E. (Ed.). Droit, sciences et techniques, quelles responsabilités? (pp. 523-541). Paris, FR: LexisNexis.

Richard, V. (2011). Learning by doing. Les procédures de réaction au nonrespect dans la Convention d'Espoo et son Protocole de Kiev. Revue juridique de l'environnement,3, 327-344.

Ruggie, J. (2011). Report of the special representative of the SecretaryGeneral on the issue of human rights and transnational corporations and other business enterprises, Guiding Principles on Business and Human Rights: Implementing the United Nations 'Protect, Respect and Remedy' Framework. U.N. Doc. A/ 
$\mathrm{HRC} / 17 / 31$.

Schedler, A. (1999). Conceptualizing Accountability. In Schedler, A., Diamond, L., \& Plattner, M. F. (Eds.), The Self-Restraining State: Power and Accountability in New Democracies (pp. 13-28). Boulder, CO: Lynne Rienner.

Schuler, G. (2008). Effective governance through decentralized soft implementation: The OECD guidelines for multinational enterprises. German Law Journal,9, 1755-1778.

Shelton, D. (Ed.). (2000). Commitment and compliance: The role of nonbinding norms in the international legal system. Oxford, UK: Oxford University Press.

Sherpa. (2010). Des palmiers et des hommes : comment la SOCAPALM viole les droits sociaux et environnementaux des communautés locales. Dec. 7, 2010. Retrieved from http://www.asso-sherpa.org/ archives/1165.

Snyder, F. (1999). Governing economic globalisation: Global legal pluralism and european law. European Law Journal,5(4), 334-374.

Stewart, R. (2008). Accountability, participation, and the problem of disregard in global regulatory governance. Draft Paper for the IILJ International Legal Theory Colloquium, Retrieved from http://iilj. org/courses/documents/2008Colloquium.Session4.Stewart.pdf

Treves, T., Tanzi, A., Pitea, C., Ragni, C. \& Pineschi, L. (Eds.). (2009). Noncompliance procedures and mechanisms and the effectiveness of international environmental agreements. The Hague, NL: TMC Asser Press.

Trindade, A.A. (2011). The access of individuals to international justice. Oxford, UK: Oxford University Press.

Vendzules, S.F. (2010). The struggle for legitimacy in environmental standards systems: The OECD guidelines for multilateral 
148 Climate Change Liability and Beyond

enterprises. Colorado Journal of International Environmental Law and Policy, 21(3), 451-490.

VERTIC (2003). Guide to verification for environmental agreements. London, UK: VERTIC.

Weiss, E. B. (1999). Understanding compliance with international environmental agreements: The baker's dozen myth. University of Richmond Law Review, 32, 1555-1589.

World Bank (2001). Making Sustainable commitments-An environment strategy for the World Bank. Washington, D.C.: The World Bank.

Young, O. R. (Ed.). (2000). The institutional dimensions of environmental change: Fit, interplay, and scale Cambridge. UK: MIT Press.

Zwanenburg, M. (2008). UN peace operations between independence and accountability. International Organizations Law Review, 5(1), 2347. 